\title{
MAGNESIUM METABOLISM IN HYPERPARATHYROIDISM
}

\author{
By HAROLD A. BULGER AND FLORENCE GAUSMANN
}

(From the Department of Internal Medicine, Washington University Medical School and Barnes Hospital, St. Louis)

(Received for publication August 7, 1933)

In an earlier, rather extensive, publication in this journal on the "Functional Pathology of Hyperparathyroidism" (1) no mention was made of magnesium metabolism. Data have now been collected permitting a contribution to this phase of the subject. The methods of study were the same as described in the previous paper (1). Magnesium determinations were made by the procedure outlined by Briggs (2).

The pharmacological relationship of calcium and magnesium ions and therefore the necessity for optimum concentrations of both in body fluids suggest a close association of the mechanisms regulating their level in the blood. The fact that magnesium phosphate has solubility properties similar to calcium phosphate and the fairly constant amount of magnesium in bone hint at a specific biological relationship of their compounds.

It would seem that the parathyroid hormone might have at least an indirect influence on magnesium metabolism. The immediate effect of parathyroid hormone on serum magnesium has been studied in dogs by Scholtz (3) and by Greenburg and Mackey (4). Their investigations showed a slight increase in serum magnesium occurring early and before the rise in calcium. By the time calcium had reached maximum values the serum magnesium had fallen towards normal. Our experiments indicated that more prolonged administration of parathormone to dogs resulted in no striking alterations in serum magnesium (Table I). This was also true with rabbits in which parathormone is not very effective in raising the serum calcium.

TABLE I

The effect of continuous parathormone administration on the serum magnesium of dogs and rabbits

Dog No. 1, parathormone, 50 to 300 units daily for 4 days....... 3.3

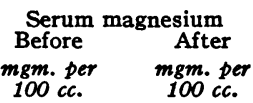

Dog No. 2, parathormone, 50 to 300 units daily for 4 days. . . . . . 3.0

Dog No. 3, parathormone, 50 to 100 units daily for 10 days. . . . . 2.2

Dog No. 4, parathormone, 50 to 100 units daily for 10 days. . . . . 2.1

Rabbit No. 1, parathormone, 10 units daily for 10 days. . . . . . 2.6

Rabbit No. 2, parathormone, 10 units daily for 10 days. . . . . 3.2

Rabbit No. 3, parathormone, 10 units daily for 10 days. . . . . . 2.8 
In clinical hypoparathyroidism serum magnesium tends to be lower than the average for normal individuals. This is not a constant or striking phenomenon. Representative values in tetany following thyroidectomy are presented in Table II. For comparison with the hypocalcaemia of parathyroid tetany this table also includes observations on patients with hypercalcaemia in generalized neoplastic disease of bone, a condition which at least simulates hyperparathyroidism. These patients also showed low normal figures for serum magnesium.

TABLE II

Serum magnesium, calcium and phosphorus of cases with hypocalcaemia and cases with hypercalcaemia

\begin{tabular}{|c|c|c|c|c|c|c|c|}
\hline \multicolumn{4}{|c|}{$\begin{array}{l}\text { Cases with hypoparathyroidism } \\
\text { following thyroidectomy }\end{array}$} & \multicolumn{4}{|c|}{$\begin{array}{l}\text { Cases with hypercalcaemia associated with } \\
\text { generalized neoplastic disease of bone }\end{array}$} \\
\hline & \multicolumn{3}{|c|}{ Serum } & & \multicolumn{3}{|c|}{ Serum } \\
\hline & $\mathrm{Mg}$ & $\mathrm{Ca}$ & $\mathbf{P}$ & & $\mathbf{M g}$ & $\mathrm{Ca}$ & $\mathbf{P}$ \\
\hline Case 11317, Tetany & $\begin{array}{c}\mathrm{mgm} . \\
\text { per } \\
100 \mathrm{cc} . \\
2.1 \\
2.6\end{array}$ & $\begin{array}{c}\begin{array}{c}\mathrm{mgm} . \\
\text { per } \\
100 \mathrm{cc}\end{array} \\
8.2 \\
7.9\end{array}$ & 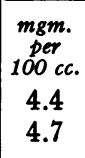 & $\begin{array}{c}\text { Case } 22810, \text { Metastatic } \\
\text { Hypernephroma }\end{array}$ & 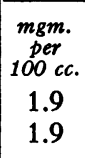 & \begin{tabular}{|c|}
$\mathrm{mgm}$. \\
per \\
$100 \mathrm{ccc}$ \\
14.9 \\
15.1 \\
\end{tabular} & $\begin{array}{c}\begin{array}{c}m g m . \\
\text { per } \\
100 \\
2 c .\end{array} \\
2.5 \\
2.7\end{array}$ \\
\hline Case 22828, Tetany & $\begin{array}{l}1.7 \\
1.7\end{array}$ & $\begin{array}{l}7.6 \\
8.8\end{array}$ & $\begin{array}{l}5.5 \\
3.7\end{array}$ & $\begin{array}{l}\text { Case C.S., Multiple } \\
\text { Myeloma }\end{array}$ & $\begin{array}{l}2.4 \\
1.8\end{array}$ & $\begin{array}{l}13.5 \\
18.1\end{array}$ & $\begin{array}{l}6.8 \\
6.2\end{array}$ \\
\hline Case 23523 , Tetany & $\begin{array}{l}1.7 \\
1.8\end{array}$ & $\begin{array}{l}7.8 \\
5.9\end{array}$ & $\begin{array}{l}7.7 \\
5.9\end{array}$ & $\begin{array}{l}\text { Case } 27621, \text { Multiple } \\
\text { Myeloma }\end{array}$ & $\begin{array}{l}2.7 \\
2.0 \\
1.8\end{array}$ & $\begin{array}{l}16.5 \\
16.9 \\
16.8\end{array}$ & $\begin{array}{l}4.4 \\
4.9 \\
4.0\end{array}$ \\
\hline
\end{tabular}

In hyperparathyroidism one finds evidence indicating more clearly that the parathyroid glands have no direct influence on the level of magnesium in the blood. This is illustrated in the studies of a typical case which will later be reported in detail by Olch. The data are recorded in Table III.

Case 26253. This patient, a woman forty years old, had always considered herself healthy. She was raised in the city. Her food habits appeared to have been quite normal. Diphtheria in childhood was the only serious infectious disease she remembered. She was married when seventeen years old. Her only pregnancy was at eighteen years and was apparently quite normal and was followed by an uneventful puerperium. About this time dental caries began to develop and careful cooperation with her dentist failed to save her teeth. Fillings continued to fall out and caries advanced until finally all her teeth were removed. Her weight was continuously around 125 pounds until her hospitalization.

Six years before admission the patient fell on the floor from the level of a bed and broke a clavicle. Three years later she fell on the ice and broke her left humerus. Two years before admission she developed dull pain above her 
TABLE III

Indicating the influence of variations in parathyroid activity on serum magnesium

\begin{tabular}{|c|c|c|c|c|}
\hline \multirow{2}{*}{$\begin{array}{l}\text { Case } 26253 \text {. Hyperparathyroidism. A parathyroid } \\
\text { adenoma removed January 8, } 1931\end{array}$} & \multicolumn{3}{|c|}{ Serum } & \multirow{2}{*}{ Date } \\
\hline & $\mathbf{M g}$ & $\mathrm{Ca}$ & $\mathbf{P}$ & \\
\hline 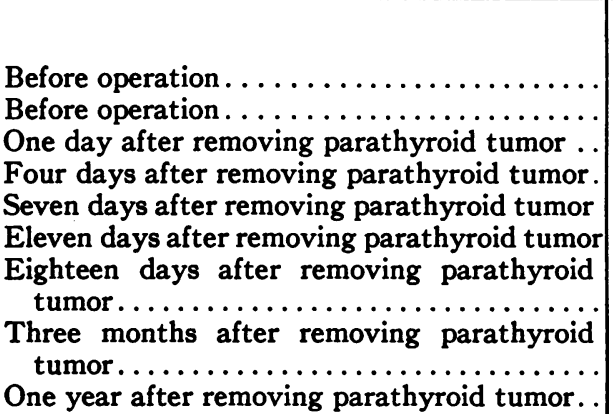 & $\begin{array}{c}\text { mgm. per } \\
100 \text { cc. } \\
1.6 \\
1.7 \\
1.7 \\
1.7 \\
1.8 \\
1.9 \\
\\
2.5 \\
\\
2.3 \\
2.5\end{array}$ & $\begin{array}{c}\text { mgm. per } \\
100 \text { cc. } \\
16.2 \\
14.0 \\
9.8 \\
8.3 \\
8.9 \\
9.6 \\
9.5 \\
\\
10.7 \\
10.2\end{array}$ & $\begin{array}{c}\text { mgm. per } \\
100 \text { cc. } \\
1.9 \\
2.3 \\
1.7 \\
1.7 \\
2.4 \\
2.1 \\
\\
2.6 \\
\\
2.4 \\
3.6\end{array}$ & $\begin{array}{l}\text { Nov. } 4,1930 \\
\text { Jan. } 8,1931 \\
\text { Jan. } 9,1931 \\
\text { Jan. } 12,1931 \\
\text { Jan. } 15,1931 \\
\text { Jan. } 19,1931 \\
\\
\text { Jan. } 26,1931 \\
\text { Apr. } 2,1931 \\
\text { Dec. } 18,1931\end{array}$ \\
\hline \multicolumn{5}{|l|}{$\begin{array}{c}\text { Case } 55690 \text {. Parathormone administration to a young } \\
\text { woman, normal except for otosclerosis }\end{array}$} \\
\hline $\begin{array}{l}\text { Before parathormone. . . . . . . . . . . . . . } \\
\text { After } 100 \text { units parathormone in } 24 \text { hours.... } \\
\text { After } 160 \text { units parathormone in } 48 \text { hours.... } \\
\text { After } 400 \text { units parathormone in } 5 \text { days..... } \\
\text { After } 580 \text { units parathormone in } 7 \text { days...... } \\
36 \text { hours after stopping parathormone...... } \\
\text { Four days after stopping parathormone..... } \\
\text { Seven days after stopping parathormone..... }\end{array}$ & $\begin{array}{l}2.2 \\
2.6 \\
2.7 \\
2.7 \\
2.6 \\
2.5 \\
2.5 \\
2.6\end{array}$ & $\begin{array}{l}10.1 \\
12.5 \\
12.5 \\
13.4 \\
12.8 \\
10.9 \\
10.3 \\
10.5\end{array}$ & $\begin{array}{l}3.7 \\
2.9 \\
2.9 \\
1.5 \\
2.3 \\
2.5 \\
3.8 \\
3.3\end{array}$ & $\begin{array}{l}\text { Sept. 20, } 1932 \\
\text { Sept. 22, } 1932 \\
\text { Sept. 23, } 1932 \\
\text { Sept. 26, } 1932 \\
\text { Sept. 28, } 1932 \\
\text { Sept. } 30,1932 \\
\text { Oct. } 3,1932 \\
\text { Oct. } 6,1932\end{array}$ \\
\hline
\end{tabular}

left knee. This was thought to be rheumatism, but, when it did not improve after months, an x-ray was taken. Her physician told her there was a lack of calcium in this area and that if she ever broke it healing might not take place. The pain gradually improved.

The patient then felt perfectly well until June 25, 1930, when she stumbled over a hedge and fell on a sidewalk and broke her left femur and right humerus. $\mathrm{X}$-ray examinations showed these to be pathological fractures through multilocular cystic areas in the bone. Further $x$-ray studies showed similar areas in other bones, especially in the pelvis and upper dorsal spine. X-ray also showed shadows in both kidney regions typical of bilateral nephrolithiasis.

Physical examination disclosed little for comment except moderate emaciation, an upper dorsal kyphosis, hyperactive deep reflexes and a systolic blood pressure of 180 and a diastolic of 100 . No tumor in the thyroid region was evident. Blood examinations showed high serum calcium, low serum phosphate, a slight anemia, normal nonprotein nitrogen and negative Wassermann and Kahn reactions. The basal metabolic rate was -4 per cent. Phenolsulphonephthalein excretion was 70 per cent.

On October 30, 1930, surgical exploration of the thyroid region by Dr. I. Y. Olch disclosed a small tumor, about 1.5 by $2 \mathrm{~cm}$. in size, in the left lobe. After this was removed the serum calcium did not fall and microscopic study showed it to be a foetal adenoma of the thyroid. On January 8,1931 , the neck was explored again and a tumor 1.5 by $4 \mathrm{~cm}$. in size was found lying in a 
crevice between the oesophagus and spine and attached by a pedicle to the upper pole of the left lobe of the thyroid. After removing this tumor the serum calcium fell to below normal and the patient experienced moderately distressing symptoms of tetany for about ten days.

Striking improvement in this patient's skeletal abnormalities, as evidenced by x-ray examinations, has followed operation. The improvement in her general condition has been less marked. The bilateral nephrolithiasis opposes a satisfactory course. Although there are no local symptoms, hypertension increases steadily and eventual kidney insufficiency is feared. Her general condition will not permit removal of the stones.

While in the hyperparathyroid state the serum magnesium varied from 1.6 to $2.0 \mathrm{mgm}$. per $100 \mathrm{cc}$. These figures are low but within the range of normal variations. Following the removal of the parathyroid adenoma the serum calcium fell typically to values below normal, but this change in state was not attended by any alteration in the level of serum magnesium. During the three weeks following operation magnesium varied from 1.8 to 2.0 . Three months later when the calcium was $10.7 \mathrm{mgm}$. and phosphorus $2.4 \mathrm{mgm}$. the serum magnesium was 2.3 mgm. per $100 \mathrm{cc}$. A year after operation the figures were about the same except that the serum phosphorus had risen to normal.

Studies of magnesium, calcium and phosphorus metabolism of this patient, with clinical hyperparathyroidism, are recorded in Table IV. Period 9, the first included in this table, was preceded by eight similar periods in which only the calcium and phosphorus were determined. As in period 9, they showed the typical negative balance of these elements. A definite tendency to lose magnesium in hyperparathyroidism is indicated by the data in this table. A significant relationship to the hyperparathyroid state is emphasized by the change in the magnesium balance which followed the extirpation of a parathyroid adenoma. As the patient was transformed to relative hypoparathyroidism and the serum calcium fell to below normal, the loss of magnesium shifted to a distinctly positive balance. Magnesium was retained as large amounts of calcium and phosphorus were stored. One year after operation the patient was studied for one period on the same diet she was following at home. This contained large amounts of magnesium, calcium and phosphorus, chiefly from milk. The retention of the three elements was still quite marked.

These modifications of magnesium excretion may be secondary to an effect of the parathyroid hormone on calcium or phosphorus of bone. It is interesting to compare the ratios of the balances of magnesium, calcium and phosphorus with the proportions of these substances in bone. Considering calcium as 100 , one may calculate the proportions shown in Table V.

It is apparent that a loss of calcium is accompanied by a loss of magnesium and phosphate and that a retention of calcium is accompanied by a retention of the other two elements as might be expected from the 


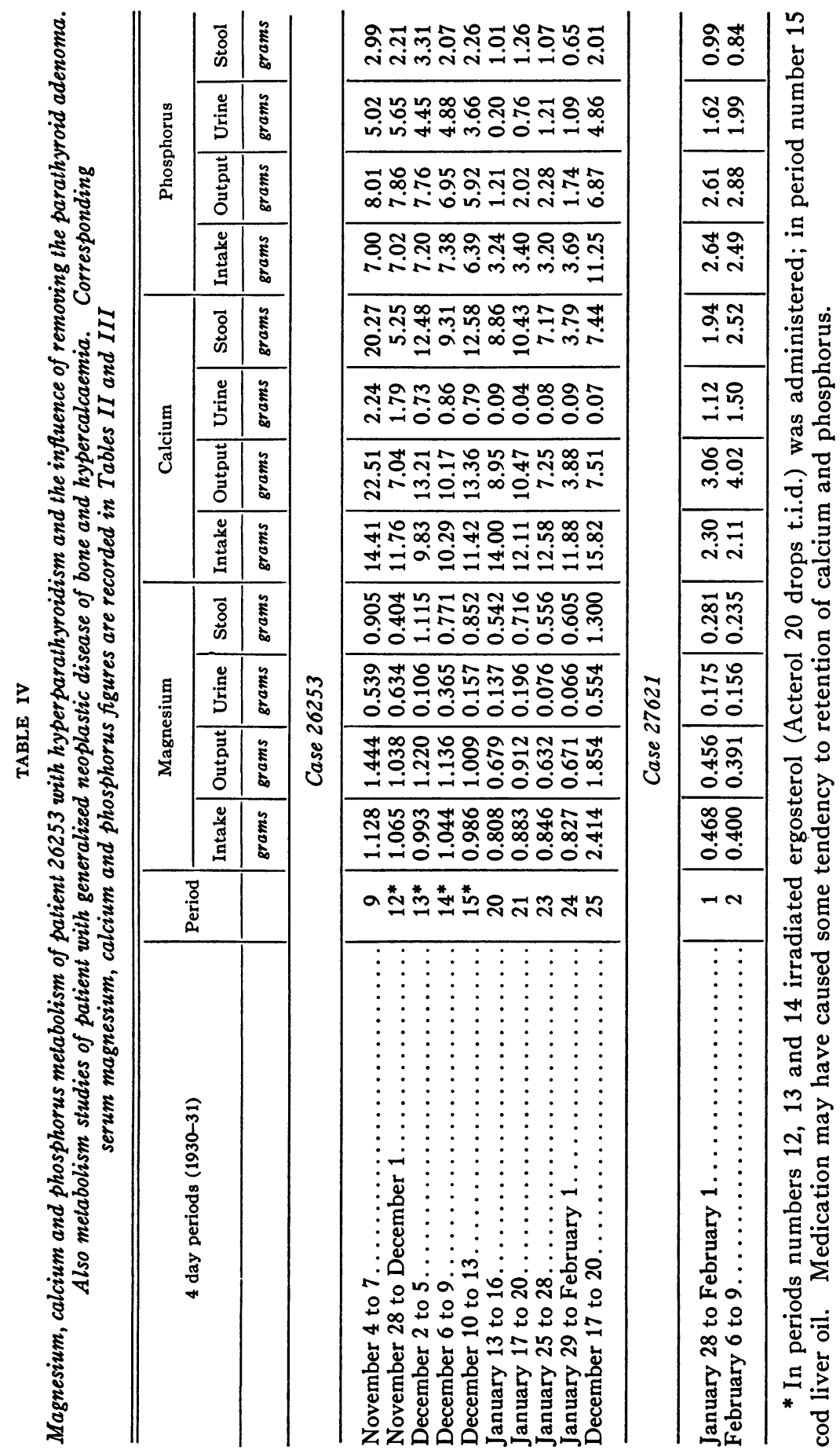


TABLE V

Ratios of magnesium and phosphorus to calcium

\begin{tabular}{|c|c|c|c|}
\hline & Calcium & Magnesium & Phosphorus \\
\hline & grams & grams & grams \\
\hline Approximate proportions in bone*. & 100 & 2 & 50 \\
\hline Loss the month before operation......... & 100 & 7.4 & 17.6 \\
\hline Retention the month after operation...... & 100 & 2.3 & 31.4 \\
\hline Retention one year after operation..... & 100 & 6.7 & 53.8 \\
\hline
\end{tabular}

* Analysis of bone from another case of hyperparathyroidism gave the following figures: Calcium 15.39 per cent, magnesium 0.23 per cent, and phosphorus 6.89 per cent. These would give ratios of $100: 1.5: 45$.

composition of bone. Significant variations from the ratios in bone do occur but further discussion of the data would not be profitable.

A study of a patient with generalized neoplastic disease of bone and hypercalcaemia is included in Table IV (Case 27621). This patient showed a markedly negative calcium balance and a slight loss of phosphorus. Nevertheless, she appeared to be in magnesium equilibrium.

Magnesium metabolism was also studied in experimental hyperparathyroidism. A young woman 27 years old, who appeared normal except for moderate undernutrition and otosclerosis, was given 70 to 100 units of parathormone (Lilly) daily for eight days. Magnesium, calcium, phosphorus, nitrogen and sulphur balances were investigated, before, during, and subsequent to the hyperparathyroid state. The results of four day periods of study are summarized in Table V. During the preliminary observations she demonstrated an ability to retain all elements, probably because of an improved dietary regimen. During the eight days of parathormone administration there was a distinct increase in magnesium output, resulting in an evident negative balance. This was due entirely to a rise in urinary magnesium excretion. The serum magnesium rose slightly. When parathormone was discontinued there was a prompt storing of magnesium but no change in the level in the serum. In these observations the mobilization of calcium and phosphorus was quite typical. The excessive phosphorus excretion was greater than could be accounted for by calcium phosphate liberated and the magnitude of the increased protein metabolism. This surplus phosphorus was more than enough to explain the magnesium loss as magnesium phosphate released from the body. In the recovery period the retention of phosphorus could reasonably be accounted for by magnesium phosphate, calcium phosphates, and protein restored.

The negative nitrogen and sulphur balance caused by parathormone may be related to the local inflammatory and slight general febrile reactions caused by the material injected rather than any specific effect of the hormone itself. 


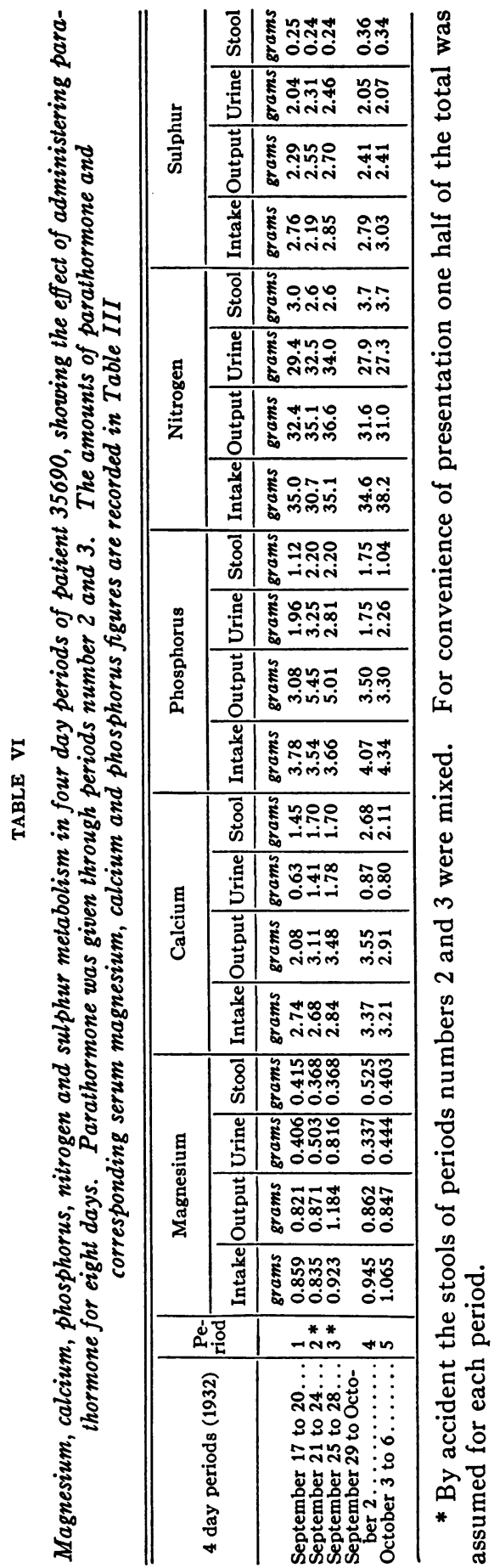




\section{CONCLUSIONS}

In the hyperparathyroid state there is a negative magnesium balance. Individuals reverting from hyperparathyroidism to normal or the hypoparathyroid state store magnesium. Little evidence was obtained indicating the parathyroid glands have any direct effect on the level of magnesium in the blood. The influence of the parathyroid hormone on magnesium metabolism may be secondary to its action on calcium or phosphorus.

\section{BIBLIOGRAPHY}

1. Bulger, H. A., Dixon, H. H., Barr, D. P., and Schregardus, Olive J., J. Clin. Invest., 1930, i, 143. The Functional Pathology of Hyperparathyroidism.

2. Briggs, A. P., J. Biol. Chem., 1922, lii, 349. A Colorimetric Method for the Determination of Small Amounts of Magnesium.

3. Scholtz, H. G., Arch. f. exp. Path. u. Pharmakol., 1931, clix, 233. Notiz über die Wirkung des Parathyreoidea-Hormons auf den Magnesiumgehalt des Blutes.

4. Greenburg, David M., and Mackey, Myrtle A., J. Biol. Chem., 1932, xcviii, 765. The Effect of Parathyroid Extract on Blood Magnesium. 